\title{
Renewable energy in sustainable supply chain: A review
}

Energía renovable en la cadena de suministro sostenible: Una revisión

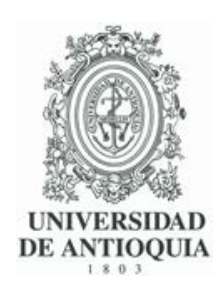

\section{Eduardo Marques (D)', Vanessa de Almeida Guimarães (D) ${ }^{2}$, Maxwel de Azevedo-Ferreira (iD ${ }^{3}$, Ronney Arismel Mancebo Boloy (D) 1}

${ }^{1}$ Mechanical Department, Centro Federal de Educação Tecnológica Celso Suckow da Fonseca CEFET/RJ. P. C. $20271-110$. Avenida Maracanã, 229. Maracanã, Rio de Janeiro, Brasil.

${ }^{2}$ Coordenação de Disciplinas Básicas e Gerais, Centro Federal de Educação Tecnológica Celso Suckow da Fonseca CEFET/RJ. P. C. 20271-110. Avenida Maracanã, 229. Maracanã, Rio de Janeiro, Brasil.

${ }^{3}$ Instituto Federal de Educação, Ciência e Tecnologia do Rio de Janeiro-Campus São João do Meriti IFRJ. P. C. $25550-110$.

Rua Vala da Divisa São João de Meriti. Rio de Jainero, Brasil.

\section{CITE THIS ARTICLE AS:}

E. Marques, V. de Almeida Guimarães, M. de Azevedo and R. A. Mancebo. "Renewable energy in sustainable supply chain: A review",Revista

Facultad de Ingeniería Universidad de Antioquia, no. 104, pp. 152-167, Jul-Sep 2022. [Online]. Available: https:

//www.doi.org/10.17533/ udea.redin. 20210956

\section{ARTICLE INFO:}

Received: January 18, 2021 Accepted: September 13, 2021 Available online: September 13,2021

\section{KEYWORDS:}

Renewable sources; supply chain; sustainable process.

Fuente renovable; cadena de suministro; proceso sustentable.
ABSTRACT: In the search for sustainable processes and products, eco-friendly policies have been developed over the years, aiming to reduce the environmental impacts as a step toward sustainability. Among the environmental impacts, alternatives to mitigate the greenhouse gas emissions - GHG stand out due to the concerns with climate change. Then, the development and use of renewable resources become relevant. Considering that the supply chains are intense in energy consumption and GHG emissions (since it involves processes related to supply, production, transport, consumption), it becomes relevant to investigate if the management of sustainable supply chain is considering the renewable energies in their processes. Therefore, this paper aims at mapping the role of renewable energies in the context of the sustainable supply chain, analyzing the literature published at Web of Science database - WoS about the subject. The main researchers, organizations, collaboration networks were presented, and the 21 most cited studies were mapped in this paper. The research was carried out with the papers published at WoS until 2019, using VantagePoint software to handle information. The findings show that the research about renewable energy in the context of a sustainable supply chain has been growing, especially since 2010. Moreover, biomass, biofuels and photovoltaic energy were the recurrent sources of renewable energy studied by most cited papers. However, the theme presented itself as new and there is still potential to be explored.

RESUMEN: En la búsqueda de procesos y productos sostenibles, se han desarrollado políticas ecológicas, con el objetivo de reducir los impactos ambientales como un paso hacia la sostenibilidad. Entre los impactos ambientales, destacan las alternativas para mitigar las emisiones de gases de efecto invernadero - GEl, debido a la preocupación por el cambio climático. Entonces, el desarrollo del uso de recursos renovables cobra relevancia. Considerando que las cadenas de suministro son intensas en consumo de energía y emisiones lya que se involucran procesos relacionados con el suministro, producción, transporte, consumol se vuelve relevante investigar si las cadenas de suministro sostenibles están considerando las energías renovables en sus procesos. Por tanto, este artículo tiene como objetivo mapear el papel de las energías renovables en el contexto de la cadena de suministro sostenible, analizando la literatura publicada en la base Web of Science. Se presentaron los principales investigadores, redes de colaboración y se mapearon los 21 estudios más citados. La investigación se llevó a cabo con los artículos publicados hasta 2019, utilizando el software VantagePoint para manejar la información. Los hallazgos muestran que las investigaciones sobre energías renovables en las cadenas de suministro sostenible han crecido, especialmente desde 2010. 
Además, la biomasa, los biocombustibles y la energía fotovoltaica fueron las fuentes de energía renovable más recurrentes. Sin embargo, el tema se presentó como nuevo y hay potencial por explorar.

\section{Introduction}

The concern about global warming has been increasing over the years [1, 2], especially after Kyoto Protocol and Paris Agreement established targets in order to reduce the greenhouse gases - GHG emissions' levels [3]. It is scientifically proven that global warming is caused by GHG emissions, especially carbon dioxide $\left(\mathrm{CO}_{2}\right)$, which is also generated by fossil fuel combustion processes [4-6]. According to some authors [7-9], the industrial sector contributes with one-half of the global energy consumption. It puts the industrial sector as the second major consumer of energy - according to IEA (International Energy Agency), it consumed 2,839,313 ktoe (kilotonnes of oil equivalent) in 2018 , behind only the transport sector that consumed 2,890,900 ktoe [10].

In this context, the supply chain is intensive in energy consumption since it involves different echelons (from raw material to manufacturing, and delivering the products for clients; sometimes, even the recycling and disposal) and process las manufacturing, transportation, and storagel. Nevertheless, the total energy consumption of each stage will depend on different features, as: whether it is a closed-loop supply chain or not, the number of echelons, the type of transformation process and technology used, where each echelon are located, which means of transportation are available and so on. In addition, Machi and Zanoni [11] explain that the total energy consumption depends on the sector and/or the product under assessment, since each of them has its own particularities. Therefore, biorefinery supply chains are different from wine or automobile supply chains.

Despite the type of supply chain, in order to reduce the energy consumption and GHG emissions, one of the solutions studied and implemented over the years is the use of renewable energies [12, 13], which covers a wide use of different technologies, as photovoltaic energy [14], hydrogen [15], wind energy [16], biogas for cogeneration [17] and many others [18-20].

According to Eurostat data (September 2020) [21] presented in Figure 1, the energy balance of renewable sources increased by almost $6 \%$ in all European Union in the last 10 years. Among the EU countries, Portugal stands out with the highest share of renewable sources in its matrix (ranging from $25 \%$ to $30 \%$ over the years). Another important fact is the growth of renewable energies in Brazil, which energy matrix include hydro, wind, solar, and bioenergy sources. According to the Brazilian Ministry of Mines and Energy [22], the renewable energy (RE) sources used in the country reached $46.1 \%$ of participation in the 2019 energy matrix, increasing $0.6 \%$ in relation to 2018 .

In relation to other parts of the world, considering the participation of primary energy from renewable sources, Canada (27.63\% in 2019) stands out in North America, Ecuador (30.38\% in 2019) in South America lafter Brazil, as presented in the previous paragraph), Morocco $(7.09 \%$ in 2019 ) in Africa, Vietnam (15.22\% in 2019) and China (12.66\% in 2019) in Asia, Turkey (18.47\%) in the Middle East and New Zealand (35.4\% in 2019) in Oceania [23].

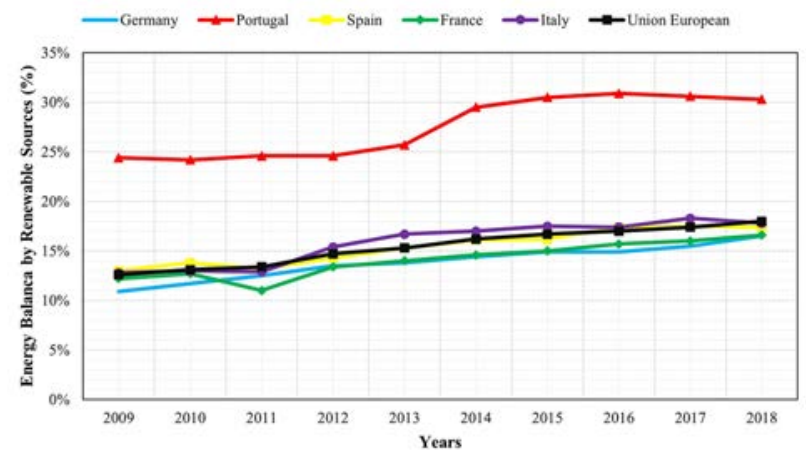

Figure 1 Energy balance from renewable sources for European Union and other countries (2020) (Source: Eurostat adapted by the authors [21])

It is essential to mention that increasing the consumption of renewable energy could also reduce the dependence on fossil energy sources, promoting a greener development $[24,25]$. It is important to highlight that the electricity and heat producers' sector are the main sources of $\mathrm{CO}_{2}$ emission in all world, according to recent data from IEA (with 13,978 $\mathrm{Mt} \mathrm{CO}_{2}$ in 2018) followed by the industrial sector (with 6,158 $\mathrm{Mt} \mathrm{CO}_{2}$ in 2018) and transport (with $8,258 \mathrm{Mt} \mathrm{CO}_{2}$ in 2018) [26].

Nevertheless, in order to achieve sustainable development, it is necessary to deal with the economic, social and environmental dimensions [27-29]. The sustainable concept was first proposed by Brutland Report in 1987 [30] then discussed in important international forums around the world, as United Nation Conferences on Sustainable Development. Nowadays, one of the most recognized agreements related to sustainable development is the 2030 Agenda from the United Nations [31], which claims the relevance of combining economic growth, social development, and environmental conservation in order to achieve sustainable development.

Therefore, according to the WWF (World Wide Fund for Naturel and the goals of the 2030 Agenda, it is necessary to harmonize economic, social and environmental 
pillars [32]. Notwithstanding, sometimes, social and environmental ones are not even taken into account [33, 34], as seen in studies about: biofuels supply chain [35, 36], solid waste supply chain [37], additive manufacturing supply chain [38], pharmaceutical supply chain [39], and others.

As global energy demand has been quite increasing laccording to data from Energy Information, 30\% of the energy consumption will increase between 2020 and 2050) [40], the business sector has still focused much of its efforts in developing actions to improve the economic performance, often leaving aside social and environmental aspects [41]. It might be related to the fact that quantifying these aspects is not always a simple task, bringing complexities in the development of decision-making support tools lincluding here mathematical optimization models) to support the decision related to the design of supply chains [42]. For example, some authors point out that the incorporation of environmental and social aspects are a challenge to the supply chain for the next years $[43,44]$; while others considering that incorporating the environmental aspect is a step toward sustainability, since there is not a consensual way to deal with the social concerns [45, 46]. However, it is possible to visualize the recent efforts of researchers to consider the three dimensions that compose the sustainable concept in the literature [47-53].

In the context of renewable energies in the supply chain, it is possible to note that some studies do not cover the triple bottom line of the sustainable concept in their analysis. Liu et al. [54], for example, proposed an optimization model for a hybrid system that uses energy from solar concentration and biomass; however, their analysis quantifies only the economic and environmental scenarios, not referring to the social impact. Câmara et al. [55] also do not take into account the social dimension: a multi-objective optimization model is proposed to assist the decision-making in hydrogen supply chain design and planning, considering the cost (economic dimension) and carbon emissions (environmental dimension). However, there are investigations that consider the three sustainable pillars, as Kristianto and Zhu [56], that model a sustainable supply chain of bio-ethanol.

Given the context presented in the previous paragraphs, the study performed in the present article was motivated by the following question: is the literature about sustainable supply chain investigating the use of renewable energy as eco-friendly policy? Therefore, this paper maps the role of renewable energies in the context of the sustainable supply chain, analyzing the literature published at Web of Science database - WoS until 2019. The main researchers, organizations, collaboration networks were presented, and the 21 most cited studies were mapped in this paper. This type of investigation is relevant since it might show some gaps and challenges to be fulfilled in future studies as well as help the academics to identify collaborations in potential. Note that we do not intend to address renewable energy as public policy, but we aim to investigate if there were studies about renewable energy among different kinds of studies performed in the literature about sustainable supply chain las addressing circular economy or life cycle assessments).

It is relevant to mention that this paper is an extended version of "The Profile of Studies on Renewable Energy in Sustainable Supply Chain", presented at ICSC-CITIES 2020 , in which we could provide further analysis of the main results related to renewable energy and sustainable supply chain.

Following this introduction, the next sections will present the methodological procedures performed to gather and analyze the data (Section 2), as well the main findings and discussion (Section 3), followed by the final considerations (Section 4).

\section{Methodological Procedures}

The methodological procedures involved a qualitative analysis of the literature and the use of techniques of descriptive statistics. Through a data mining process, the articles were obtained from the WoS database. The database was chosen due to its satisfactory scope and coverage [57], and for being used in papers with similar methodology as [58], [33]. Table 1 shows the parameters of the search.

Table 1 Description of search performed in the Web of Science database

\begin{tabular}{cc}
\hline Criteria & Description \\
\hline Keywords & TS = ("SUPPLY CHAIN*" OR “SUPPLY NETWORK*”) \\
& AND ("SUSTAINAB*”) \\
\hline Database & Web of Science \\
\hline Refinement & Only Articles published in Journals until \\
\hline Data & March 20, 2020 - 16:20 GMT-3 \\
\hline
\end{tabular}

As you may note, at first, the study did not include any keyword related to renewable energy sources, since we decided to gather all the papers published about sustainable supply chain (or supply network) and then, select a frame for analysis (renewable energy). By doing that, we reduce the possible error related to the exclusion of papers that could be related to the subject but do not use a specific keyword as the indexation terms.

Once the search was done, the next phase was to determine the keywords that would be used to select our 
subset among the results. The selected keywords can be divided into three categories: (i) energy las sustainable energy, electricity, bioenergy, wind energy, solar energy, solar photovoltaic and so on); (ii) bioenergy sources las ethanol, palm oil, algal biofuel and so on); (iii) supply chain (biomass Supply Chain, Bioethanol Supply Chain, Hydrogen Supply Chain and so on). It is important to point out that there were 260 keywords related to renewable energy in an 11,333 words database. Then, only those papers that had, at least, one keyword related to any kind of renewable energy were selected to perform the analysis proposed in this article.

Figure 2 presents the frequency of each category of renewable energies sources found among the keywords, highlighting that the largest amount is represented by biomass, followed by biofuel, ethanol, solar, photovoltaic, and hydrogen.

After establishing the subset of papers that deal with renewable energy among the sustainable supply chain studies, the data analysis was carried out using the VantagePoint software. The main results and discussions are presented in Section 3.

\section{Results and Discussion}

As discussed in the methodological procedures, at first, we performed a broad search, according to the criteria presented in Table 1. Considering the frame of publication years (1900-2019), the search reported 9,558 documents, of which only 6,984 were indexed articles published in journals.

Based on these results, the next step considered only the papers published in journals lexcluding proceedings, for example). Then, among the 6,984 articles, we selected only those that had, at least, one keyword related to renewable energy sources. After this step, only 547 studies remained in our database, representing $5.7 \%$ of the papers published in WoS about the sustainable supply chain.

Figure 3 shows how the studies that address renewable energy in sustainable supply chains have been developed over the years. The red triangles represent the relative frequency of the papers published (records) over the years and, the blue one is the tendency line. The interest in this subject is recent: the first paper published about the sustainable supply chain in WoS database is from 1996; however, the first paper indexed with a keyword related to renewable energy was published only in 2002 . The blue line shows a tendency of accentuated growth from 2010.

The second analysis sought to understand the collaboration network among the main authors. total of 1.777 authors were found in the database, but none of them had published more than 15 papers over the years. The 10 (ten) authors with the largest number of papers published about the subject were, respectively; You, FQ (with 12 records), Bezzo, F (7), Faaij, APC (7), Junginger, M (7), Ponce-Ortega, JM (7), Zhang, J (7), Cucchiella, F (6), D’Adamo, I (6), Lam, HL (6) and Osmani, A (6).

The author's collaboration network is presented in Figure 4. There are two strongly connected networks circled in green. There are also small networks, composed of 3 authors or more, and collaboration in pairs. Besides, it is possible to identify the collaboration networks established by the most relevant authors (circled in red in Figure 4). The most relevant authors are: How, BS; Lam, HL; Ng, WPQ; Cucchiella, F; D’Adamo, I; Guo, M; Shah, N; Giarola, S; Bezzo, F; Murphy, RJ; Gonela, V; Osmani, A; Zhang, J. It is important to highlight that Figure 4 considered only those authors with, at least, four publications about the subject.

Table 2 lists the 28 authors with, at least, 4 publications, while Table 3 shows the 18 most cited authors (the names highlighted with an asterisk in Table 3 are the authors who appeared in both tables). By comparing Tables 2 and 3, we realize that the author with the highest number of papers published about the subject (You, FQ) is also the second most cited author in this database (after only European Comission). Santibanez-Aguillar, JE (4st in Table 2) and Yue D.J. (5st) also appear among the most cited authors (Table 3). In addition, it is observed in Figure 4, that these three mentioned authors have collaboration networks with the most cited and/or among those who publish the most, as the case of Ponce-Ortega and Santibanez-Aguilar, Zhang and Osmani, Bezzo and Shah and others.

It is also possible to identify the main organizations and institutions that have published the most about the subject of this article. The principal results led to: Imperial College of Science, Technology, and Medicine (with 16 records), University of Padua (14), Iran University Science and Technology (12), University of Utrecht (11), Wageningen University (11), University of Groningen (10), Northwestern University (9), Oak Ridge National Laboratory (9), University of California (9) and University of Manchester (9). It is important to emphasize that there are other institutions besides universities in the database, for example, Natural Resources Canada (4), Argonne National Laboratory (3) and US Forest Service (3).

Note that, despite having $46.1 \%$ of renewable sources in the Brazilian Energy Matrix (as discussed in the Introduction), there is no Brazilian organization among the most relevant ones. The Brazilian university that publishes the most about the subject is Federal Fluminense University, 


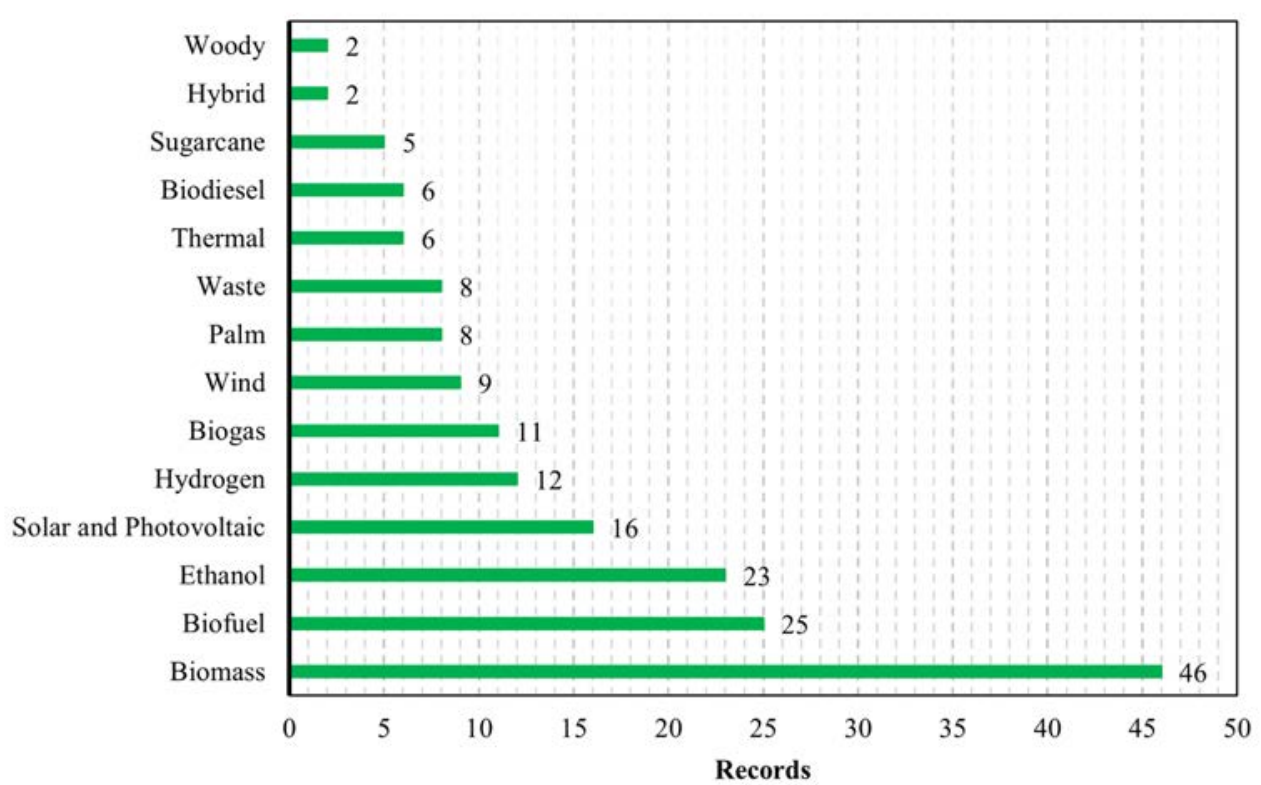

Figure 2 Most recurrent keywords related to RE in the sustainable supply chain's articles published at WoS until 2019

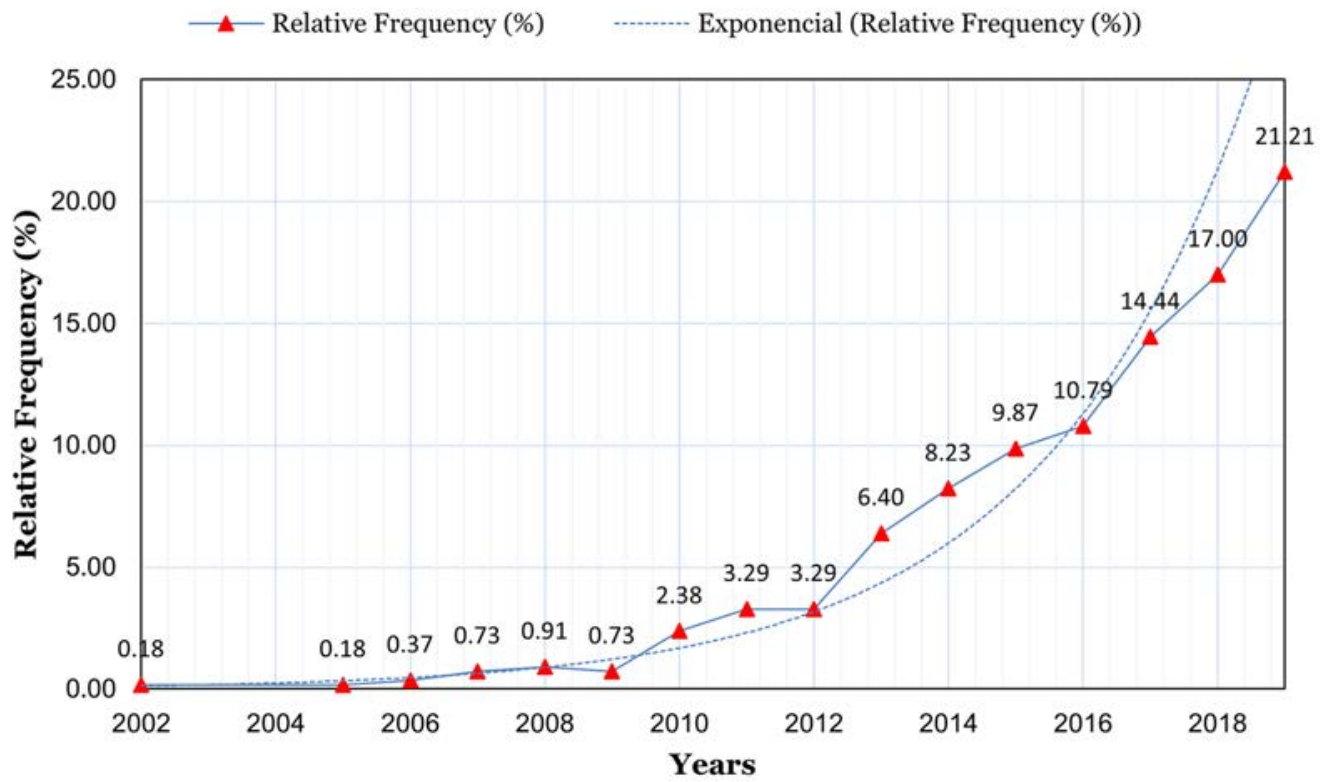

Figure 3 Evolution of sustainable supply chain and renewable energies records in the function of years

with 4 records in the database. UFF is followed by Federal University of Rio de Janeiro - UFRJ (3), São Paulo University - USP (3), Federal Technological University of Paraná - UTFPR (2) and Univ Fed Santa Catarina (2). There are other Brazilian organizations with one record only, including a company in the energy area: Petrobras.

Regarding the countries that published the most about the subject, the top 10 are: USA (with 145 records),
United Kingdom (67), Italy (63), Netherlands (45), Germany (34), China (30), Australia (26), Canada (25), Brazil (25) and Malaysia (24). Figure 5 shows the distribution of publications around the world (the colors are related to the number of publications in each countryl. It is important to note that, although some countries in Africa, the Middle East, and Latin America have not contributed to the research area, it is a topic that has been studied widely on a global scale. The countries with the largest publications 


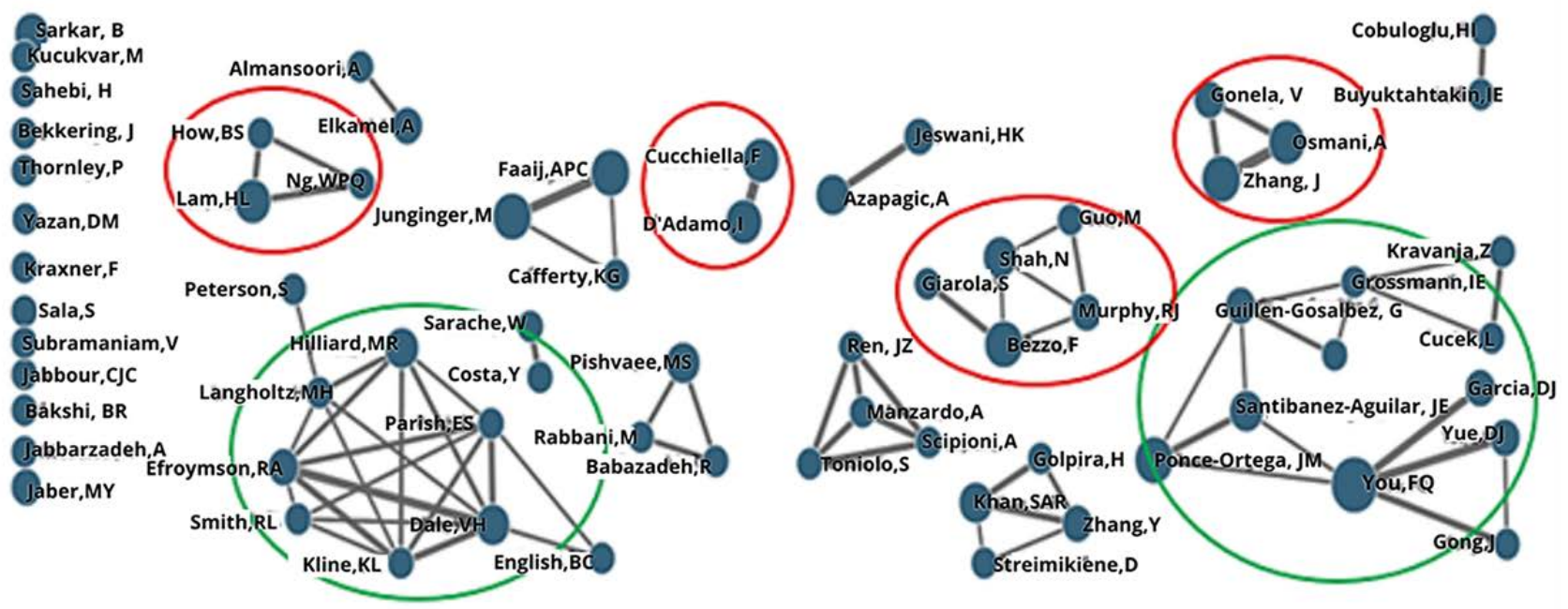

Figure 4 Collaboration networks and micro-networks between the various authors found in the database

Table 2 Authors with the largest number of publications about the sustainable supply chain and RE database

\begin{tabular}{ccc}
\hline Position & Author & Records \\
\hline $1^{\circ}$ & You, FQ & 12 \\
\hline \multirow{3}{*}{$2^{\circ}$} & Bezzo, F & 7 \\
& Faaij, APC & 7 \\
& Junginger, M & 7 \\
& Ponce-Ortega, JM & 7 \\
Zhang, J & 7 \\
\hline \multirow{3}{*}{$3^{\circ}$} & Cucchiella, F & 6 \\
& D'Adamo, I & 6 \\
& Lam, HL & 6 \\
Osmani, A & 6 \\
\hline \multirow{4}{*}{$4^{\circ}$} & Azapagic, A & 5 \\
& Dale, VH & 5 \\
& Hilliard, MR & 5 \\
Khan, SAR & 5 \\
& Pishvaee, MS & 5 \\
& Santibanez-Aguilar, JE & 5 \\
& Sarkar, B & 5 \\
Shah, N & 5 \\
\hline \multirow{4}{*}{$5^{\circ}$} & Efroymson, RA & 4 \\
& Elkamel, A & 4 \\
& Garcia, DJ & 4 \\
Gonela, V & 4 \\
& Guillen-Gosalbez, G & 4 \\
Jaber, MY & 4 \\
Jeswani, HK & 4 \\
Murphy, RJ & 4 \\
Yue, DJ & 4 \\
Zhang, Y & 4 \\
\hline
\end{tabular}

by the continent are: the USA in North America (145), Brazil in South America (25), Mexico in Central America (16), UK in Europe (67), China in Asia (30), and Australia in Oceania (26).
Table 3 The 18 most cited authors in the database for sustainable supply chain and RE

\begin{tabular}{ccc}
\hline Position & Cited Authors & Records \\
\hline $1^{\circ}$ & Commission European & 66 \\
\hline $2^{\circ}$ & You, FQ* & 61 \\
\hline $3^{\circ}$ & International Energy Agency (IEA) & 54 \\
\hline $4^{\circ}$ & Cucek L. & 50 \\
& Kim Jongdeuk & 50 \\
\hline $5^{\circ}$ & Yue, DJ* & 45 \\
\hline $6^{\circ}$ & Gold Stefan & 44 \\
\hline $7^{\circ}$ & International Organization for Standardization (ISO) & 42 \\
\hline $8^{\circ}$ & Food and Agriculture Organization (FAO) & 36 \\
\hline $9^{\circ}$ & Giarola S. & 35 \\
\hline $10^{\circ}$ & Sokhansanj S. & 34 \\
\hline $11^{\circ}$ & Rentizelas Athanasios A. & 33 \\
& Santibanez-Aguilar, JE* & 33 \\
\hline 120 & Eksioglu S. D. & 32 \\
& Zamboni A. & 32 \\
\hline $13^{\circ}$ & Cherubini F. & 31 \\
\hline $14^{\circ}$ & Shabani, N & 30 \\
& Sharma, B & 30 \\
\hline
\end{tabular}

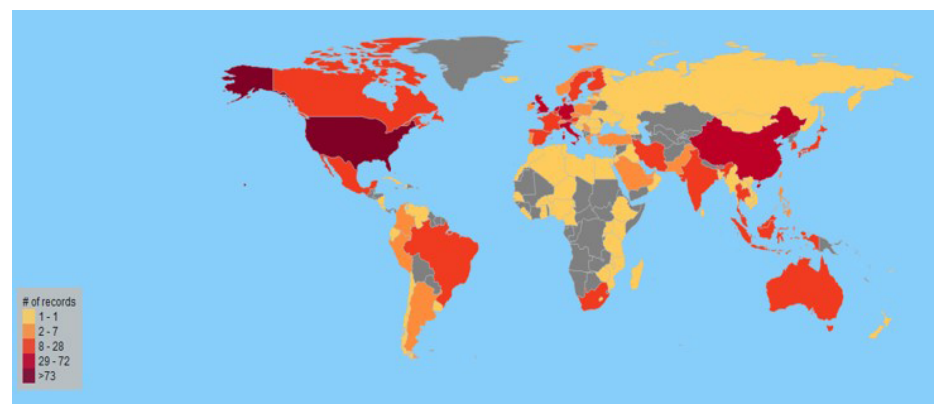

Figure 5 Publications about sustainable supply chain and renewable energy across the world 
Table 4 Mapping of the most cited works about sustainable supply chain and RE

\begin{tabular}{|c|c|c|c|c|}
\hline Author & Objective & Energy Source & Supply Chain & $\begin{array}{c}\text { Sustainable } \\
\text { Criteria }\end{array}$ \\
\hline $\begin{array}{l}\text { You et al. (2011) } \\
\text { [59] }\end{array}$ & $\begin{array}{l}\text { Design of cellulosic } \\
\text { ethanol supply } \\
\text { chain under } \\
\text { sustainable criteria }\end{array}$ & $\begin{array}{c}\text { Biomass } \\
\text { (switchgrass and } \\
\text { miscanthus) }\end{array}$ & $\begin{array}{l}\text { Cellulosic ethanol } \\
\text { supply chain }\end{array}$ & $\begin{array}{c}\text { - Emissions of GHG } \\
\text { - Job creation } \\
\text { - Cost (total } \\
\text { annualized apital } \\
\text { cost and the annual } \\
\text { operation cost) }\end{array}$ \\
\hline $\begin{array}{c}\text { Yue, You and } \\
\text { Snyder (2014) [60] }\end{array}$ & $\begin{array}{l}\text { Describe the key } \\
\text { challenges and } \\
\text { opportunities in } \\
\text { optimization of } \\
\text { biomass-to } \\
\text { bioenergy supply } \\
\text { chains }\end{array}$ & $\begin{array}{c}\text { Biomass (algae) } \\
\text { (agricultural/forest) }\end{array}$ & $\begin{array}{c}\text { Biofuel/bioenergy } \\
\text { supply chain }\end{array}$ & $\begin{array}{l}\text { - Emissions of } \mathrm{GHG} \\
\text { - Emissions of } \mathrm{CO}_{2} \\
\text { - Job creation } \\
\text { - Cost loperation } \\
\text { cost - transport } \\
\text { and the biofuel } \\
\text { production) }\end{array}$ \\
\hline $\begin{array}{l}\text { Gold and Seuring } \\
\text { (2011) [61] }\end{array}$ & $\begin{array}{c}\text { Literature review } \\
\text { about bio-energy } \\
\text { production }\end{array}$ & Biomass & $\begin{array}{c}\text { Bio-energy supply } \\
\text { chain }\end{array}$ & $\begin{array}{l}\text { - Emissions of } \mathrm{CO}_{2} \\
\text { - Transport Traffic } \\
\text { - Cost (storage, } \\
\text { feedstock, and the } \\
\text { transport cost) }\end{array}$ \\
\hline $\begin{array}{c}\text { Choudhary and } \\
\text { Shankar (2012) [62] }\end{array}$ & $\begin{array}{l}\text { Propose a STEEP- } \\
\text { fuzzy AHP-TOPSIS } \\
\text { based framework } \\
\text { for evaluation and } \\
\text { selection of } \\
\text { locations of }{ }^{1} T P P s\end{array}$ & Coal & $\begin{array}{c}\text { Bio-energy supply } \\
\text { chain }\end{array}$ & $\begin{array}{l}\text { - Environmental } \\
\text { impact } \\
\text { - Cost (land } \\
\text { acquisition, } \\
\text { resettlement, and } \\
\text { the infrastructure) }\end{array}$ \\
\hline $\begin{array}{l}\text { Goodrich et al. } \\
\text { (2013) [63] }\end{array}$ & $\begin{array}{c}\text { Analysis of } \\
\text { manufacturing } \\
\text { costs for } \\
\text { wafer-based } \\
\text { monocrystalline } \\
{ }^{2} P V \text { module supply } \\
\text { chain }\end{array}$ & ${ }^{20} P V$ & $\begin{array}{l}{ }^{2} P V \text { module supply } \\
\text { chain }\end{array}$ & $\begin{array}{l}\text { • Cost } \\
\text { (manufacturing and } \\
\text { operational cost) } \\
\text { - Energy Efficiency }\end{array}$ \\
\hline $\begin{array}{l}\text { Ahmad and Tahar } \\
\qquad \text { (2014) [64] }\end{array}$ & $\begin{array}{l}\text { Review and } \\
\text { selection of a }{ }^{3} R E \\
\text { source in Malaysia }\end{array}$ & $\begin{array}{c}\text { Hydropower, Wind, } \\
{ }^{2} P V \text {,Biogas and } \\
\text { Biomass }\end{array}$ & $\begin{array}{c}\text { Energy generation } \\
\text { supply chain }\end{array}$ & $\begin{array}{c}\text { - Emissions of } \mathrm{CO}_{2} \\
\text { - Environmental } \\
\text { impact } \\
\text { - Job creation } \\
\text { - Public acceptance } \\
\text { - Cost } \\
\text { (technologies } \\
\text { investment costs) }\end{array}$ \\
\hline $\begin{array}{c}\text { Mccormick and } \\
\text { Kaberger (2007) } \\
{[65]}\end{array}$ & $\begin{array}{l}\text { Analysis, and } \\
\text { discussion of } \\
\text { barriers for } \\
\text { bioenergy in the } \\
{ }^{4} \mathrm{EU}\end{array}$ & Biomass and Biogas & $\begin{array}{c}\text { Bio-energy supply } \\
\text { chain }\end{array}$ & $\begin{array}{c}\text { - Emissions of GHG } \\
\text { - Job creation } \\
\text { - Cost linvestment } \\
\text { and management } \\
\text { cost) }\end{array}$ \\
\hline $\begin{array}{l}\text { Scott et al. (2012) } \\
{[66]}\end{array}$ & $\begin{array}{l}\text { Review of problems } \\
\text { in bioenergy sector } \\
\text { using }{ }^{5} M C D M\end{array}$ & $\begin{array}{c}\text { Biomass, }{ }^{2} P V \text { Wind, } \\
\text { Hydrogen }\end{array}$ & $\begin{array}{l}\text { Biomass/Biofuel } \\
\text { supply chain }\end{array}$ & $\begin{array}{l}\text { - Emissions of } \mathrm{GHG} \\
\text { - Emissions of } \mathrm{CO}_{2} \\
\text { - Environmental } \\
\text { impact } \\
\text { - Job creation } \\
\text { - Public acceptance } \\
\text { - Cost (electricity, } \\
\text { investment, and } \\
\text { operational cost) }\end{array}$ \\
\hline
\end{tabular}




\begin{tabular}{|c|c|c|c|c|}
\hline $\begin{array}{c}\text { Zangh et al. (2013) } \\
\text { [67] }\end{array}$ & $\begin{array}{c}\text { Propose a } \\
\text { mathematical } \\
\text { model to } \\
\text { determine the } \\
\text { optimal supply } \\
\text { chain/logistics } \\
\text { decisions of }{ }^{6} S B S C\end{array}$ & $\begin{array}{c}\text { Biomass } \\
\text { (Switchgrass) }\end{array}$ & $\begin{array}{c}\text { Bioethanol supply } \\
\text { chain }\end{array}$ & $\begin{array}{c}\text { • Energy } \\
\text { consumption } \\
\text { - Cost loperational } \\
\text { - transportation, } \\
\text { cultivation, and } \\
\text { storage cost) }\end{array}$ \\
\hline $\begin{array}{c}\text { Cucchiella and } \\
\text { D’Adamo (2013) } \\
\text { [68] }\end{array}$ & $\begin{array}{l}\text { Literature review of } \\
\text { supply chain and } \\
{ }^{3} R E\end{array}$ & $\begin{array}{l}\text { Biomass, hydrogen, } \\
{ }^{2} P V \text { and Wind } \\
\text { power }\end{array}$ & $\begin{array}{c}{ }^{3} R E \text { supply } \\
\text { chain/supply chain } \\
\text { management }\end{array}$ & $\begin{array}{l}\text { - Emissions of GHG } \\
\text { - Job creation } \\
\text { - Cost (Life Cycle } \\
\text { Costing - LCC, } \\
\text { electricity, } \\
\text { operational and } \\
\text { maintenance cost) }\end{array}$ \\
\hline $\begin{array}{l}\text { Corsano et al. } \\
\text { (2011) [69] }\end{array}$ & $\begin{array}{c}\text { Propose a }{ }^{7} M I N L P \\
\text { optimization model } \\
\text { for a sustainable } \\
\text { design and } \\
\text { behavior analysis of } \\
\text { sugar/ethanol } \\
\text { supply chain (SC) }\end{array}$ & $\begin{array}{c}\text { Biomass } \\
\text { (Sugarcane) }\end{array}$ & $\begin{array}{l}\text { Sugar/ethanol } \\
\text { supply chain }\end{array}$ & $\begin{array}{c}\text { • Cost } \\
\text { (transportation, } \\
\text { installation, } \\
\text { investment, } \\
\text { treatment, and } \\
\text { operational cost) } \\
\text { - Environmental } \\
\text { impact }\end{array}$ \\
\hline $\begin{array}{l}\text { Cucchiella et al. } \\
\text { (2015) [70] }\end{array}$ & $\begin{array}{l}\text { Environmental and } \\
\text { economic analysis } \\
\text { of building- } \\
\text { integrated } \\
\text { photovoltaic } \\
\text { systems in italian } \\
\text { regions }\end{array}$ & ${ }^{2} P V$ & ${ }^{2} P V$ supply chain & $\begin{array}{c}\text { - Emissions of } \mathrm{CO}_{2} \\
\text { - Energy Efficiency } \\
\text { - Energy } \\
\text { consumption } \\
\text { - Cost (investment, } \\
\text { installation, } \\
\text { maintenance, and } \\
\text { the emission cost) }\end{array}$ \\
\hline $\begin{array}{c}\text { Stokes et al. (2011) } \\
\text { [71] }\end{array}$ & $\begin{array}{l}\text { Quantifying the } \\
\text { life-cycle energy } \\
\text { consumption and } \\
\text { associated air } \\
\text { emissions from } \\
\text { water supply, } \\
\text { treatment, and } \\
\text { distribution }\end{array}$ & Natural Gas & $\begin{array}{c}\text { Water distribution } \\
\text { and treatment } \\
\text { supply chain }\end{array}$ & $\begin{array}{c}\text { - Emissions of } \mathrm{CO}_{2} \\
\text { - Emissions of } \mathrm{GHG} \\
\text { - Energy } \\
\text { consumption }\end{array}$ \\
\hline $\begin{array}{c}\text { Chiaroni et al. } \\
\text { D'Adamo (2014) [72] }\end{array}$ & $\begin{array}{l}\text { Debate concerning } \\
\text { self-consumption } \\
\text { to support the } \\
\text { economic } \\
\text { sustainability of } \\
\text { photovoltaic } \\
\text { facilities }\end{array}$ & ${ }^{2} P V$ & ${ }^{2} P V$ supply chain & $\begin{array}{l}\text { - Cost (investment, } \\
\text { electrical and } \\
\text { maintenance cost) } \\
\text { - Energy Efficiency }\end{array}$ \\
\hline $\begin{array}{c}\text { Khan et al. (2018) } \\
\text { [73] }\end{array}$ & $\begin{array}{l}\text { Investigate the } \\
\text { relationship } \\
\text { between green } \\
\text { logistics operations } \\
\text { and energy } \\
\text { demand, economic } \\
\text { growth and } \\
\text { environmental } \\
\text { sustainability for } 43 \\
\text { countries }\end{array}$ & Biomass & $\begin{array}{l}\text { Industrial/biofuel } \\
\text { supply chain } \\
\text { management }\end{array}$ & $\begin{array}{l}\text { - Emissions of } \mathrm{CO}_{2} \\
\text { - Emissions of } \mathrm{GHG} \\
\text { - Cost (logistics) }\end{array}$ \\
\hline
\end{tabular}




\begin{tabular}{|c|c|c|c|c|}
\hline $\begin{array}{c}\text { Andrews and } \\
\text { Shabani (2012) [74] }\end{array}$ & $\begin{array}{l}\text { Role of Hydrogen in } \\
\text { global } \\
\text { sustainable energy } \\
\text { strategy }\end{array}$ & Hydrogen & $\begin{array}{l}\text { Hydrogen supply } \\
\text { chain }\end{array}$ & $\begin{array}{c}\text { - Emissions of GHG } \\
\text { - Energy } \\
\text { consumption } \\
\text { - Transport Traffic }\end{array}$ \\
\hline $\begin{array}{c}\text { Cherubini and } \\
\text { Jungmeier (2010) } \\
\text { [75] }\end{array}$ & $\begin{array}{l}\text { Comparative } \\
\text { analysis of a } \\
\text { biorefinery with } \\
\text { fossil energy } \\
\text { systems (LCA) }\end{array}$ & $\begin{array}{c}\text { Biomass } \\
\text { (Switchgrass) }\end{array}$ & $\begin{array}{c}\text { Biorefinery, Oil and } \\
\text { Natural gas supply } \\
\text { chain }\end{array}$ & - Emissions of $\mathrm{GHG}$ \\
\hline $\begin{array}{l}\text { Wu et al. (2016) } \\
\text { [76] }\end{array}$ & $\begin{array}{c}\text { Stochastic energy } \\
\text { management } \\
\text { of a smart home }\end{array}$ & ${ }^{2} P V$ & $\begin{array}{l}\text { PV power supply } \\
\text { chain }\end{array}$ & $\begin{array}{c}\text { • Energy } \\
\text { consumption } \\
\text { - Cost (electricity } \\
\text { production and } \\
\text { consumption) }\end{array}$ \\
\hline $\begin{array}{c}\text { Rosa and } \\
\text { Christensen (2011) } \\
\text { [77] }\end{array}$ & $\begin{array}{c}\text { Study of the energy } \\
\text { performance of a } \\
\text { low-energy } \\
\text { network }\end{array}$ & Biomass & $\begin{array}{l}\text { Heat networks } \\
\text { supply chain* }\end{array}$ & - Energy Efficiency \\
\hline $\begin{array}{l}\text { Lund et al. (2010) } \\
\text { [78] }\end{array}$ & $\begin{array}{c}\text { Discussion and } \\
\text { identification of } \\
\text { environmental } \\
\text { consequences } \\
\text { electricity supplies } \\
\text { (LCA) }\end{array}$ & $\begin{array}{l}\text { Wind Power with } \\
\text { cogeneration }\end{array}$ & $\begin{array}{l}\text { Eletricity Supply } \\
\text { chain* }\end{array}$ & - Emissions of $\mathrm{CO}_{2}$ \\
\hline $\begin{array}{l}\text { Dewulf et al. (2005) } \\
\text { [79] }\end{array}$ & $\begin{array}{l}\text { Energetic analysis } \\
\text { of biofuels based } \\
\text { on rapeseed } \\
\text { soybean and corn }\end{array}$ & Biomass & $\begin{array}{l}\text { Biofuel Supply } \\
\text { Chain }\end{array}$ & $\begin{array}{c}\text { • Energy } \\
\text { consumption } \\
\text { - Emissions of } \mathrm{CO}_{2}\end{array}$ \\
\hline
\end{tabular}


Figure 6 lists the collaboration network among the 10 largest publishing countries. It is seen that the USA, Canada, and the UK are in the middle of the network (representing points of connection between the main nations) and that have the largest international collaboration networks.

After analyzing the main authors and their networks, organizations and countries, the next step seeks to understand what the main areas of research are interested in the subject "sustainable supply chains and renewable energies" (Figure 7). As expected, the main results are related to the energy, engineering, and technology areas, as follows: Energy \& Fuels (with 221 records - represents $18.60 \%$ of the areas), Engineering (213 - 17.93\%), Environmental Sciences \& Ecology (201 - 16.92\%), Science \& Technology - Other Topics (157 - 13.22\%), Biotechnology \& Applied Microbiology (70 - 5.89\%), Agriculture (57 - 4.80\%), Business \& Economics $(46$ $3.87 \%$ ), Thermodynamics (33 - 2.78\%), Computer Science (28 - 2.36\%) and Operations Research \& Management Science $(27-2.27 \%)$.

Other areas were observed that seem not to be directly related to renewable energies but that involve decision-making processes (such as transportation, mathematics, and telecommunication), which leads to a conclusion that the different industrial segments are looking for sustainable alternatives to minimize the environmental impacts in the supply chain.

Figure 8 shows the evolution of the research areas over the years. The first four (Energy \& Fuels, Engineering, Environmental Science \& Ecology and Science \& Technology - Other Topicsl increased the number of publications over the last six years, having achieved their greater records in 2019. The other areas presented oscillations over the years.

Besides, it is possible to identify the keywords most recurrent in the studies. As presented in Figure 9, the most frequent keywords are biomass (61), bioenergy (58), biofuel (53), energy (41), renewable energy (41), palm oil (28), bioethanol (19), and others. Also, Figure 10 presents the top 20 keywords and their matching networks with each other, noting that in the middle between all the words, the terms are always seen, sustainability, supply chain, life cycle assessment, biofuel, bioenergy, biomass, optimization, and renewable energy.

Finally, we performed a literature review of the 21 most cited papers about the subject, aiming at identifying the energy sources and the sustainable criteria mentioned in each study. It is important to mention that, despite not having enough citation records to be listed in Table 4, the database gathered other relevant papers that address renewable energy in a sustainable supply chain that might be investigated by researchers interested in the subject. Besides, the papers published in the last three years could be analyzed in future works in order to identify novelties and different approaches in the area. Note that You, FQ; Lam, HL; Yue,DJ; Cucchiella, F; D’Adamo, I and Khan, SAR (the main authors presented in Table 2), have papers listed among the most cited in Table 4. Another important fact is that some of the most cited articles were published in the last five years (2016 and 2018).

Regarding the goals of each paper, we realize that renewable energy in the supply chain is a broad area of interest, as previously presented in Figures 7 and 8. Therefore, some papers evaluate and/or propose mathematical models to enhance energy performance, while others only compare the performance of different systems and/or studies novel sources of biofuels.

Moreover, Figure 6 shows the frequency of each source energy, sustainable criteria and supply chain presented in Table 5. Although the findings cannot be extended to the entire database, it was identified that biomass and photovoltaic were the most investigated renewable sources in Table 4, as well as, biofuel and bioenergy were the most studied type of supply chain. Cost lan economic indicator) and $\mathrm{CO}_{2}$ and $\mathrm{GHG}$ emissions lan environmental indicator) were the sustainable criteria more recurrent in the database. It is in accordance with the literature [41], [45], [80] that points out the difficulty in considering social indicators. When the social impact is evaluated, job creation is the indicator addressed the most.

At the end, we can point out that renewable energy is a topic of interest in sustainable supply chain studies all over the world. However, incorporating the social aspects might be a challenge for future studies, as it is in other areas as transportation [45] and facility location [33], [42], [58].

\section{Conclusion}

In this paper, we answered some questions related to the main researchers, institutions, and countries that have been investigating about sustainable supply chain and renewable energy, the increase or decrease about publications within this area, and the most significant issues related to this subject. After answering them, it was possible to map the role of renewable energies in the context of the sustainable supply chain, from the literature published at Web of Science database - WoS until 2019.

This paper showed that the investigation of renewable energies in the sustainable supply chain is a recent concern: the first paper published about the subject was 
Table 5 Mapping of the most recurrent categories in the 21 most cited articles

\begin{tabular}{cccc}
\hline Category & Type & Frequency & Relative Frequency in the 21 Articles \\
\hline \multirow{5}{*}{ Source Energy } & Biomass & 13 & $61.90 \%$ \\
& Photovoltaic & 7 & $33.33 \%$ \\
& Wind Power & 4 & $19.04 \%$ \\
& Hydrogen & 3 & $14.28 \%$ \\
& Biogas & 2 & $9.52 \%$ \\
& Hydropower & 1 & $4.76 \%$ \\
\hline \multirow{5}{*}{ Sustainable Criteria } & 15 & $71.42 \%$ \\
& Cost & 9 & $42.85 \%$ \\
& Emissions of $C O_{2}$ & 9 & $42.85 \%$ \\
& Emissions of GHG & 6 & $28.57 \%$ \\
& Job Creation & 6 & $28.57 \%$ \\
& Energy Consumption & 4 & $19.04 \%$ \\
& Energy Efficiency & 4 & $19.04 \%$ \\
& Environmental impact & 2 & $9.52 \%$ \\
\hline \multirow{5}{*}{ Supply Chain } & Public Acceptance & $33.33 \%$ \\
& Biofuel Supply Chain & 7 & $28.57 \%$ \\
& Bioenergy Supply Chain & 6 & $19.04 \%$ \\
\hline
\end{tabular}

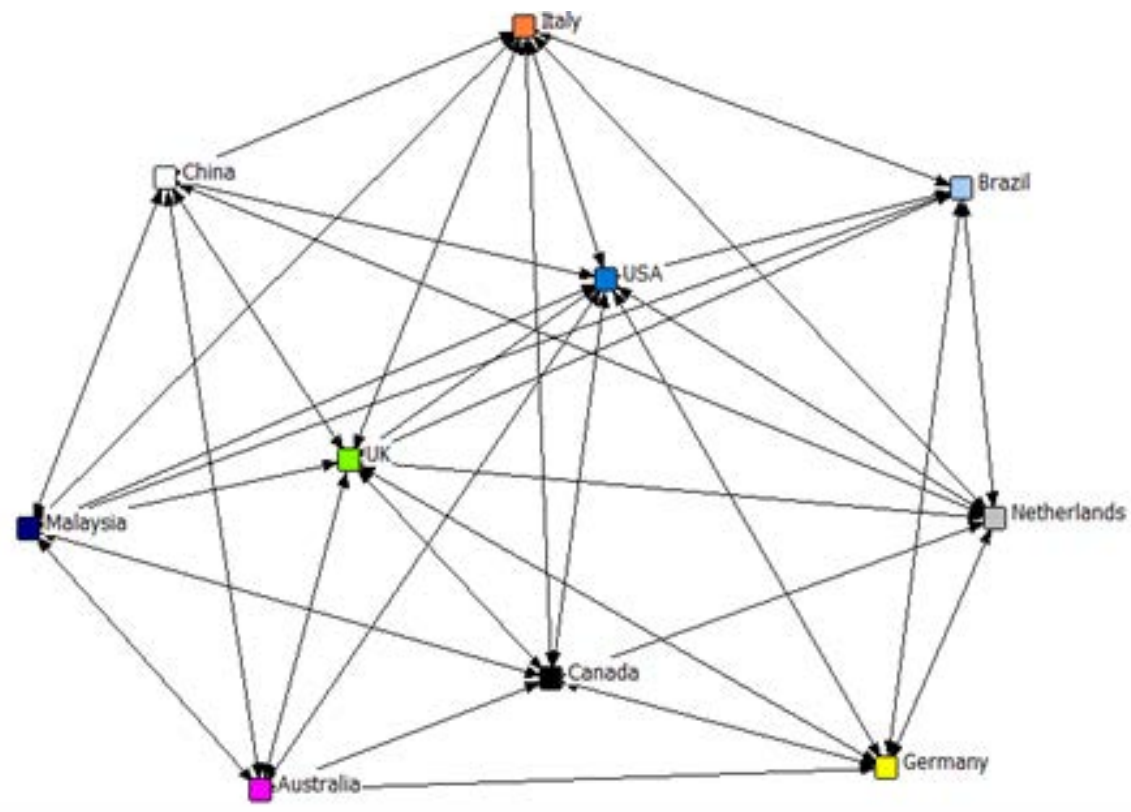

Figure 6 Collaboration network of 10 most publishers' countries

in 2002, but there was an intensification on its growth only from 2010. Among the most cited papers, only three were published before 2010 .

Furthermore, this research showed that different countries and institutions around the world are searching for solutions related to renewable energies in the supply chain (as can be seen in Figure 5). Another important remark is that different industrial sectors have developed research in this area, ranging from the pharmaceutical to food industry, according to Figure 7.
This research also showed a diversity of renewable energy sources that have been investigated, from biomass, biofuels, and bioenergy, to photovoltaic, wind energy and biogas. Regarding the sustainable criteria, we identified emphasis in the economic (cost) and environmental (GHG or specifically $\mathrm{CO}_{2}$ emissions) among the 21 most cited papers. However, we must emphasize that a social criterion was mentioned in four papers: job creation. It reinforces that considering the triple bottom line is a challenge for future studies.

It is important to mention that despite representing 


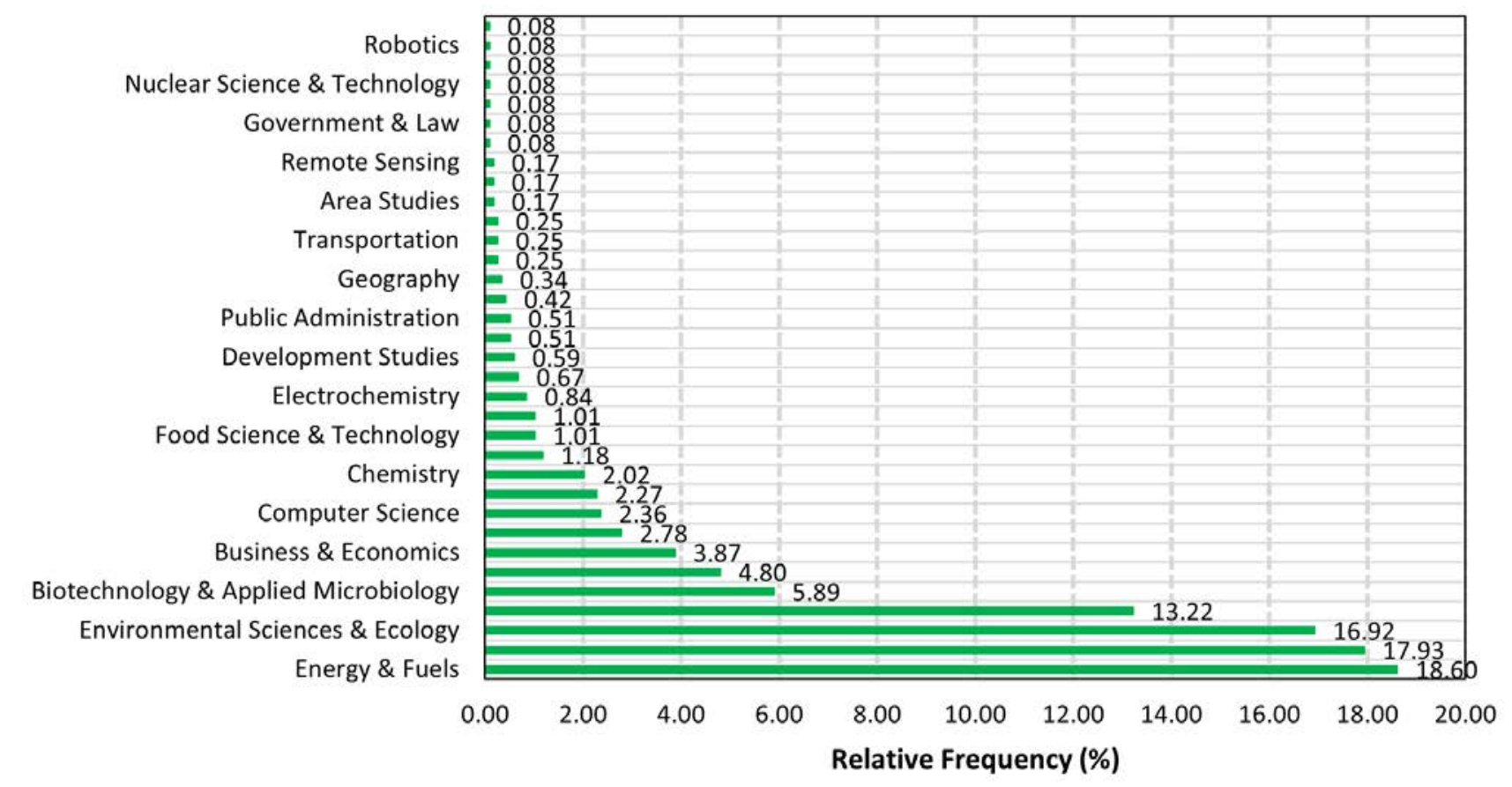

Figure 7 Research areas and the relative frequency of the records

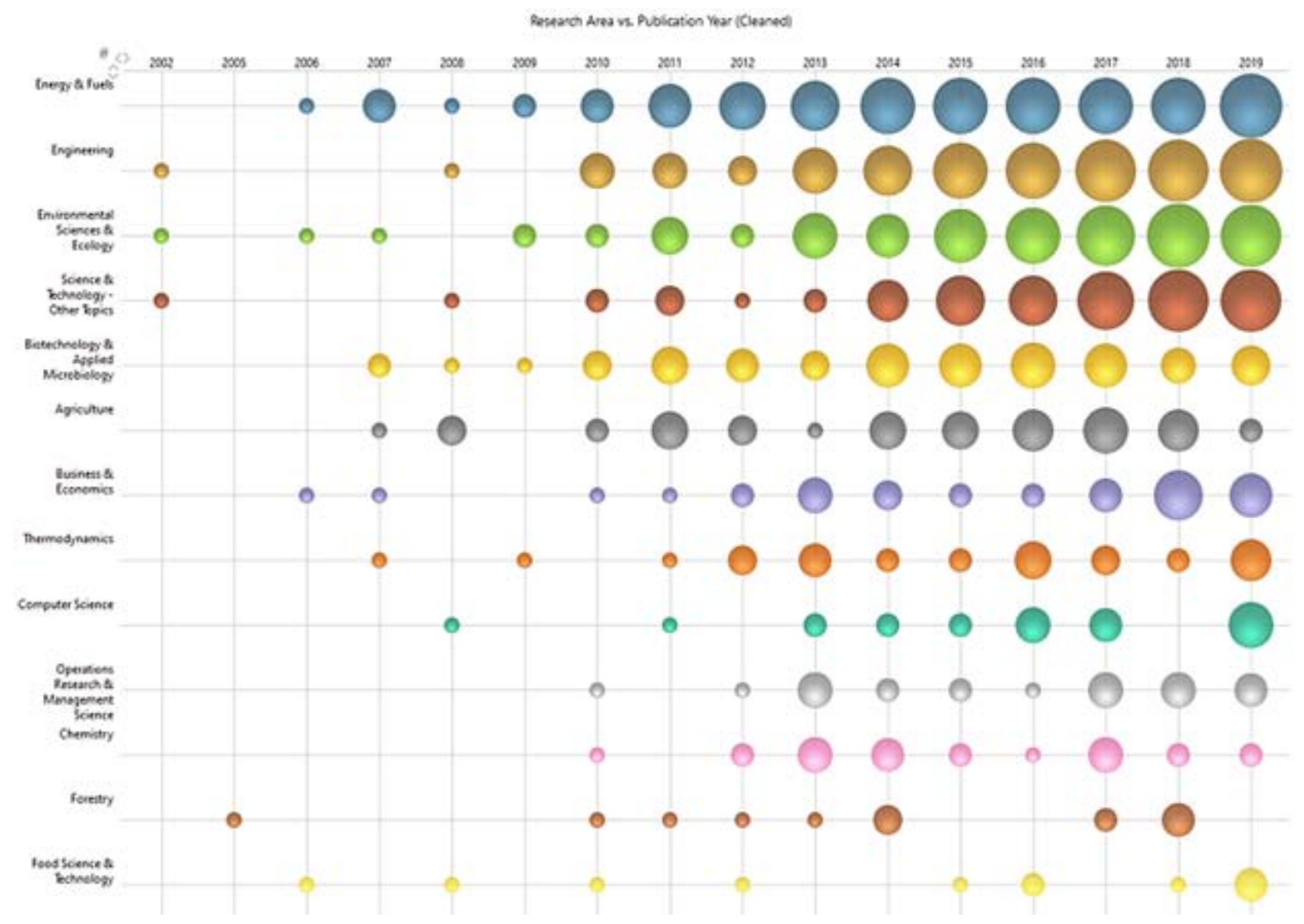

Figure $\mathbf{8}$ Research areas vs. Publication Year 


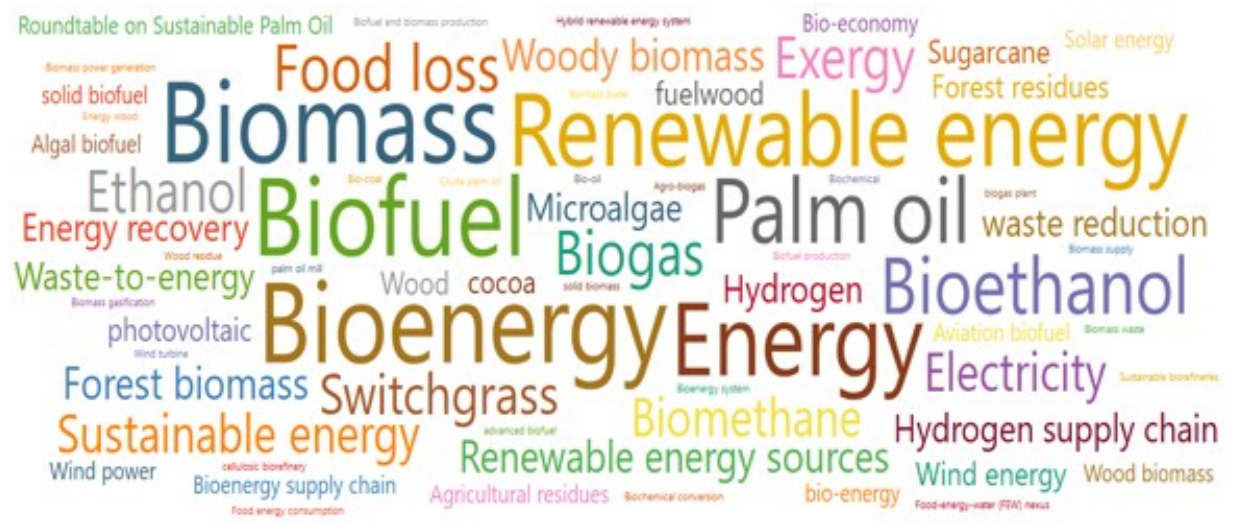

Figure 9 Word cloud with the most frequent keywords in the database (Source: Research data)

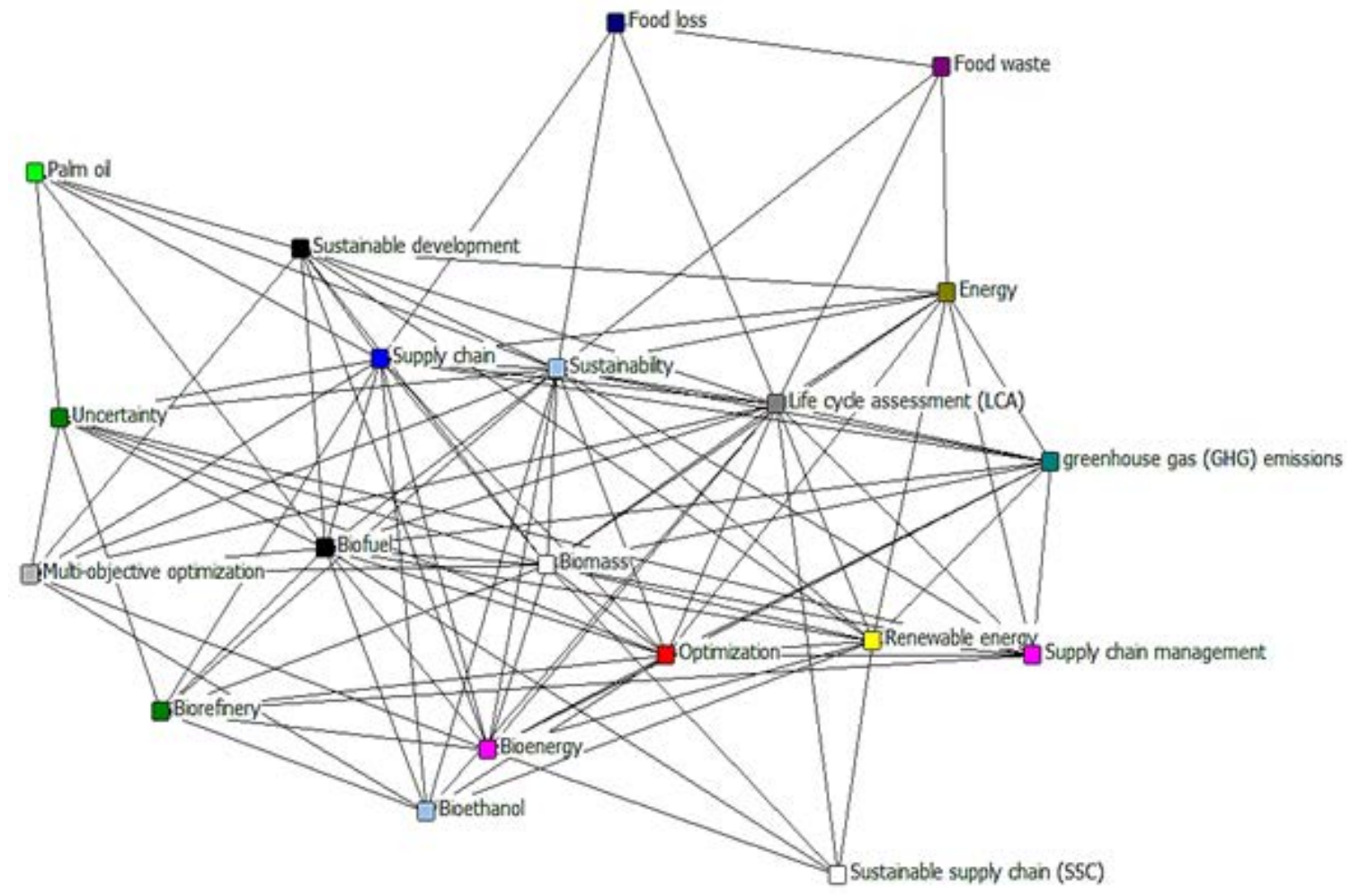

Figure 10 The 20 keywords most recurrent and their networks (Source: Research data)

only $5.7 \%$ of the papers published about sustainable supply chains at WoS, there are more than 500 papers investigating the role of renewable in the search for more sustainable supply chains. Likewise, it is relevant to highlight that the literature points out the development of biofuels and renewable sources of energy as eco-friendly policies themselves. These ecofriendly policies aim to reduce the environmental impact, especially consumption of fossil fuels, depletion of natural resources, and $\mathrm{CO}_{2}$ emissions level $[30,31]$. Therefore, we have answered the main question of this research.
As limitations of this research, we highlight that the coverage of this research included only the papers published on the Web of Science database, and the results are directly influenced by the keywords selected for the review. Besides, a literature review was performed only with the 21 most cited papers labout $3.83 \%$ of the database).

As suggestions, we point out that future works could investigate other aspects of the sustainable supply chain database, segregating the studies by type of supply chain or renewable energy. Besides, further analysis could propose 
a theoretical framework to help in the assessment of the economic, social, and environmental dimensions in the sustainable supply chain.

\section{Declaration of competing interest}

The authors declare that we have no significant competing interests, including financial or non-financial, professional, or personal interests interfering with the full and objective presentation of the work described in this manuscript.

\section{Funding}

The authors would like to thank CNPq by the scholarship awarded to support this research, IFRJ for the availability of VantagePoint software and the project "Ciudades Inteligentes, totalmente integrales, eficiente y sostenibles (CITIES), n. de processo: 518RT0557".

\section{Author contributions}

Eduardo Marques - Writing and Research; Vanessa de Almeida Guimarães - Supervision and Methodological Design; Maxwel de Azevedo-Ferreira - Methodological Support and Figure Editor; Ronney Arismel Mancebo Boloy - Co-supervision.

\section{Data Availability Statement:}

The details of the research are in the methodological procedures and the data were collected on the Web of Science database (https://www.webofknowledge.com) and processed with the Vantage Point software

\section{References}

[1] J. Y. Ding, S. Song, and C. Wu, "Carbon-efficient scheduling of flow shops by multi-objective optimization," European Journal of Operational Research, vol. 248, no. 3, Feb. 1, 2016. [Online]. Available: https://doi.org/10.1016/j.ejor.2015.05.019

[2] E. Mastrocinque, F. J. Ramírez, A. Honrubia-Escribano, and D. T. Pham, "An AHP-based multi-criteria model for sustainable supply chain development in the renewable energy sector," Expert Systems with Applications, vol. 150, Jul. 15, 2020. [Online]. Available: https://doi.org/10.1016/j.eswa.2020.113321

[3] S. Oberthür and H. E. Ott, The Kyoto Protocol: international climate policy for the 21st century. Springer Science \& Business Media, 1999.

[4] S. E. Hosseini, "An outlook on the global development of renewable and sustainable energy at the time of COVID-19," Energy Research \& Social Science, vol. 68, Oct. 2020. [Online]. Available: https: //doi.org/10.1016/j.erss.2020.101633

[5] E. Huang and et al., "Multi-objective optimization for sustainable renewable jet fuel production: A case study of corn stover based supply chain system in Midwestern U.S." Renewable and
Sustainable Energy Reviews, vol. 115, Nov. 2019. [Online]. Available: https://doi.org/10.1016/j.rser.2019.109403

[6] C. J. C. Jabbour, A. B. L. de S. Jabbour, J. Sarkis, and M. G. Filho, "Unlocking the circular economy through new business models based on large-scale data: An integrative framework and research agenda," Technological Forecasting and Social Change, vol. 144, Jul. 2019. [Online]. Available: https://doi.org/10.1016/j.techfore.2017. 09.010

[7] K. Fang, N. Uhan, F. Zhao, and J. W. Sutherland, "A new approach to scheduling in manufacturing for power consumption and carbon footprint reduction," Journal of Manufacturing Systems, vol. 30, no. 4, Oct. 2011. [Online]. Available: https://doi.org/10.1016/j.jmsy.2011. 08.004

[8] 0. A. Olanrewaju, "Energy consumption in South African industry: A decomposition analysis using the LMDI approach," Energy \& Environment, vol. 29, no. 2, Ene. 8, 2018. [Online]. Available: https://doi.org/10.1177/0958305X17745364

[9] H. Jiang, X. Zhang, X. Shao, and J. Bao, “How Do the Industrial Structure Optimization and Urbanization Development Affect Energy Consumption in Zhejiang Province of China?" Sustainability, vol. 10, no. 6, Jun. 5, 2018. [Online]. Available: https://doi.org/10.3390/ su10061889

[10] IEA World Energy Balances 2020. IEA - International Energy Agency. Accessed Apr. 7, 2021. [Online]. Available: http://nedwww.ipac. caltech.edu/

[11] B. Marchi and S. Zanoni, "Supply Chain Management for Improved Energy Efficiency: Review and Opportunities," Energies, vol. 10, no. 10, Oct. 16, 2017. [Online]. Available: https://doi.org/10.3390/ en10101618

[12] J. Maroušek, S. Hašková, R. Zeman, J. Váchal, and R. Vaníčková, "Assessing the implications of EU subsidy policy on renewable energy in Czech Republic," Clean Technologies and Environmental Policy, vol. 17, no. 2, Feb. 2015. [Online]. Available: https: //doi.org/10.1007/s10098-014-0800-1

[13] A. Kuriqi, A. N. Pinheiro, A. Sordo-Ward, and L. Garrote, "Influence of hydrologically based environmental flow methods on flow alteration and energy production in a run-of-river hydropower plant," Journal of Cleaner Production, vol. 232, Sep. 2019. [Online]. Available: https://doi.org/10.1016/j.jclepro.2019.05.358

[14] L. Hernández-Callejo, S. Gallardo-Saavedra, and V. Alonso-Gómez, "A review of photovoltaic systems: Design, operation and maintenance," Solar Energy, vol. 188, Ago. 2019. [Online]. Available: https://doi.org/10.1016/j.solener.2019.06.017

[15] J. G. F. Madeira and et al., "Ecological analysis of hydrogen production via biogas steam reforming from cassava flour processing wastewater," Journal of Cleaner Production, vol. 162, Sep. 20, 2017. [Online]. Available: https://doi.org/10.1016/j.jclepro. 2017.06.076

[16] S. Deep, A. Sarkar, M. Ghawat, and M. K. Rajak, "Estimation of the wind energy potential for coastal locations in India using the Weibull model," Renewable Energy, vol. 161, Dic. 2020. [Online]. Available: https://doi.org/10.1016/j.renene.2020.07.054

[17] Y. A. de Oliveira Chaves, M. V. Springer, R. A. M. Boloy, O. M. de Castro Ferreira Soares, and J. G. F. Madeira, "Performance Study of a Microturbine System for Cogeneration Application Using Biogas from Manipueira," BioEnergy Research, vol. 13, no. 2, Jun. 2020. [Online]. Available: https://doi.org/10.1007/s12155-019-10071-0

[18] P. E. Escamilla-García, R. H. Camarillo-López, R. Carrasco-Hernández, E. Fernández-Rodríguez, and J. M. Legal-Hernández, "Technical and economic analysis of energy generation from waste incineration in Mexico," Energy Strategy Reviews, vol. 31, Sep. 2020. [Online]. Available: https: //doi.org/10.1016/j.esr.2020.100542

[19] L. Samylingam and et al., "Thermal and energy performance improvement of hybrid PV/T system by using olein palm oil with MXene as a new class of heat transfer fluid," Solar Energy Materials and Solar Cells, vol. 218, Dic. 2020. [Online]. Available: https://doi.org/10.1016/j.solmat.2020.110754

[20] B. Koçak, A. I. Fernandez, and H. Paksoy, "Review on sensible thermal energy storage for industrial solar applications and 
sustainability aspects," Solar Energy, vol. 209, Oct. 2020. [Online]. Available: https://doi.org/10.1016/j.solener.2020.08.081

[21] Estatísticas das Energias Renováveis. Eurostat. Accessed Sep. 17, 2020. [Online]. Available: https://bit.ly/3oPFPFV

[22] M. de Minas e Energia. (2014, Jul. 31,) Fontes renováveis sobem 0,6 ponto percentual na Matriz Energética. Governo Federal. Accessed Sep. 24, 2020. [Online]. Available: https://bit.ly/2SmWrJ8

[23] H. Ritchie and M. Roser, "Renewable Energy," Our World in Data, 2020. [Online]. Available: https://ourworldindata.org/ renewable-energy

[24] A. Alper and 0. Oguz, "The role of renewable energy consumption in economic growth: Evidence from asymmetric causality," Renewable and Sustainable Energy Reviews, vol. 60, Jul. 2016. [Online]. Available: https://doi.org/10.1016/j.rser.2016.01.123

[25] Q. Wang and L. Zhan, "Assessing the sustainability of renewable energy: An empirical analysis of selected 18 European countries," Science of The Total Environment, vol. 692, Nov. 20, 2019. [Online]. Available: https://doi.org/10.1016/j.scitotenv.2019.07.170

[26] CO2 Emissions Statics. International Energy Agency. Accessed Nov. 17, 2019. [Online]. Available: https://www.iea.org/statistics/ co2emissions/

[27] A. Krings and T. M. Schusler, "Equity in sustainable development: Community responses to environmental gentrification," International Journal of Social Welfare, vol. 29, no. 4, May. 27, 2020. [Online]. Available: https://doi.org/10.1111/ ijsw. 12425

[28] D. Gonzalez-Cabezas, C. Zaror, and M. Herrera, "Comparative assessment of sustainable development in South American countries on the basis of the Sustainable Society Index," International Journal of Sustainable Development \& World Ecology, vol. 26, no. 1, 2019. [Online]. Available: https://doi.org/10.1080/13504509.2018. 1540022

[29] A. Khan, Y. Chenggang, S. Bano, and J. Hussain, "The empirical relationship between environmental degradation, economic growth, and social well-being in Belt and Road Initiative countries," Environmental Science and Pollution Research, vol. 27, no. 24, May. 30, 2020. [Online]. Available: https://doi.org/10.1007/ s11356-020-09058-8

[30] ONU, "Our Common Future: Report of the World Commission on Environment and Development," Our common future, vol. 17, Jul. 10, 1987. [Online]. Available: http://www.un-documents.net/ocf-02. htm

[31] United Nations. (2015) Transforming our World: The 2030 Agenda for Sustainable Development. [Online]. Available: https://sdgs.un. org/2030agenda

[32] 0 que é desenvolvimento sustentável? WWF-Brasil. Accessed Abr. 8, 2021. [Online]. Available: https://bit.ly/3fmKXy8

[33] E. Marques and V. Guimarães, "The Influence of Facility Location on the Sustainability of Smart Cities: Current Literature Analysis," in In Efficient, Sustainable, and Fully Comprehensive Smart Cities: II Ibero-American Congress of Smart Cities (ICSC-CITIES 2019), L. H. Callejo and C. L. Z. Cañón, Eds. Soria: Universidad Santiago de Cali, 2020.

[34] D. C. Gong, P. H. Li, P. S. Chen, and F. Wang, "Supply chain network design with multi-time-period stochastic demands for optimizing dual objectives on economic and environmental factors," Journal of the Chinese Institute of Engineers, vol. 43, no. 1, 2020. [Online]. Available: https://doi.org/10.1080/02533839.2019.1676651

[35] M. Rezaei, S. K. Chaharsooghi, A. H. Kashan, and R. Babazadeh, "Optimal design and planning of biodiesel supply chain network: a scenario-based robust optimization approach," International Journal of Energy and Environmental Engineering, vol. 11, no. 1, Mar. 2020. [Online]. Available: https://doi.org/10.1007/s40095-019-00316-1

[36] J. M. Lopes, I. C. L. Junior, and V. D. A. Guimarães, "Impact of Modal Choice in Energy Consumption and Carbon Dioxide Emissions: Analysis of Brazilian Bioethanol Supply Chain," Brazilian Journal of Operations \& Production Management, vol. 13, no. 2, Jun. 2016. [Online]. Available: https://doi.org/10.14488/BJOPM.2016.v13.n2.a1

[37] I. Ghalehkhondabi and R. Maihami, "Sustainable municipal solid waste disposal supply chain analysis under price-sensitive demand:
A game theory approach," Waste Management \& Research: The Journal for a Sustainable Circular Economy, vol. 38, no. 3, 2020. [Online]. Available: https://doi.org/10.1177/0734242X19886650

[38] S. Chowdhury, O. Shahvari, M. Marufuzzaman, J. Francis, and L. Bian, "Sustainable design of on-demand supply chain network for additive manufacturing," IISE Transactions, vol. 51, no. 7, Feb. 8, 2019. [Online]. Available: https://doi.org/10.1080/24725854.2018. 1532134

[39] I. Halim, P. Ang, and A. Adhitya, "A decision support framework and system for design of sustainable pharmaceutical supply chain network," Clean Technologies and Environmental Policy, vol. 21, no. 2, Mar. 5, 2019. [Online]. Available: https://doi.org/10.1007/ s10098-018-1646-8

[40] A. Kahan. (2019, Sep. 24,) EIA projects nearly 50usage by 2050, led by growth in Asia. Energy International Agency. Accessed Ago. 31, 2020. [Online]. Available: https://www.eia.gov/todayinenergy/detail. php?id=41433

[41] C. Gahm, F. Denz, M. Dirr, and A. Tuma, "Energy-efficient scheduling in manufacturing companies: A review and research framework," European Journal of Operational Research, vol. 248, no. 3, Feb. 1, 2016. [Online]. Available: https://doi.org/10.1016/j.ejor.2015.07.017

[42] R. Z. Farahani, M. SteadieSeifi, and N. Asgari, "Multiple criteria facility location problems: A survey," Applied Mathematical Modelling, vol. 34, no. 7, Jul. 2010. [Online]. Available: https://doi.org/10.1016/ j.apm.2009.10.005

[43] A. B. Arabani and R. Z. Farahani, "Facility location dynamics: An overview of classifications and applications," Computers \& Industrial Engineering, vol. 62, no. 1, Feb. 2012. [Online]. Available: https://doi.org/10.1016/j.cie.2011.09.018

[44] S. Luthra, K. Govindan, D. Kannan, S. K. Mangla, and C. P. Garg, "An integrated framework for sustainable supplier selection and evaluation in supply chains," Journal of Cleaner Production, vol. 140, no. Parte 3, Ene. 1, 2017. [Online]. Available: https: //doi.org/10.1016/j.jclepro.2016.09.078

[45] V. de Almeida Guimarães and I. C. L. Junior, "Performance assessment and evaluation method for passenger transportation: a step toward sustainability," Journal of Cleaner Production, vol. 142, no. Parte 1, Ene. 20, 2017. [Online]. Available: https: //doi.org/10.1016/j.jclepro.2016.05.071

[46] V. de A. Guimarães, G. M. Ribeiro, V. L. do Forte, and A. Lucena, "A Location-Allocation Model for Logistics Integration Centers," International Journal of Transport Economics= Rivista Internazionale de Economia dei Trasporti, vol. 44, no. 2, Jun. 2017. [Online]. Available: https://trid.trb.org/view/1492181

[47] S. A. Yawar and S. Seuring, "Management of Social Issues in Supply Chains: A Literature Review Exploring Social Issues, Actions and Performance Outcomes," Journal of Business Ethics, vol. 141, no. 3, Mar. 2017. [Online]. Available: https://doi.org/10.1007/ s10551-015-2719-9

[48] D. R. Krause, S. Vachon, and R. D. Klassen, "Special topic forum on sustainable supply chain management: introduction and reflections on the role of purchasing management," Journal of Supply Chain Management, vol. 45, no. 4, Oct. 2009. [Online]. Available: https://doi.org/10.1111/j.1745-493X.2009.03173.x

[49] C. R. Carter and D. S. Rogers, "A framework of sustainable supply chain management: moving toward new theory," International Journal of Physical Distribution \& Logistics Management, vol. 38, no. 5, Jun. 13, 2008. [Online]. Available: https://doi.org/10.1108/ 09600030810882816

[50] X. Liang, X. Zhao, M. Wang, and Z. Li, “Small and Medium-Sized Enterprises Sustainable Supply Chain Financing Decision Based on Triple Bottom Line Theory," Sustainability, vol. 10, no. 11, Nov. 16, 2018. [Online]. Available: https://doi.org/10.3390/su10114242

[51] 0. Narimissa, A. Kangarani-Farahani, and S. Molla-Alizadeh-Zavardehi, "Evaluation of sustainable supply chain management performance: Indicators," Sustainable Development, vol. 28, no. 1, 2020. [Online]. Available: https://doi.org/10.1002/sd.1976

[52] Y. Kazancoglu, Y. D. Ozkan-Ozen, and M. Ozbiltekin, "Minimizing losses in milk supply chain with sustainability: An example from an 
emerging economy," Resources, Conservation and Recycling, vol. 139, Dic. 2018. [Online]. Available: https://doi.org/10.1016/j.resconrec. 2018.08.020

[53] K. Petridis, E. Grigoroudis, and G. Arabatzis, "A goal programming model for a sustainable biomass supply chain network," International Journal of Energy Sector Management, vol. 12, no. 1, Mar. 20, 2018. [Online]. Available: https: //doi.org/10.1108/IJESM-09-2017-0002

[54] M. Liu, K. H. van Dam, A. M. Pantaleo, and M. Guo, "Optimisation of Integrated Bioenergy and Concentrated Solar Power Supply Chains in South Africa," Computer Aided Chemical Engineering, vol. 43, 2018. [Online]. Available: https://doi.org/10.1016/B978-0-444-64235-6. 50255-2

[55] D. Câmara, T. Pinto-Varela, and A. P. Barbósa-Povoa, "Multi-objective optimization approach to design and planning hydrogen supply chain under uncertainty: A Portugal study case," Computer Aided Chemical Engineering, vol. 46, 2019. [Online]. Available: https://doi.org/10.1016/B978-0-12-818634-3.50219-8

[56] Y. Kristianto and L. Zhu, "Techno-economic optimization of ethanol synthesis from rice-straw supply chains," Energy, vol. 141, Dic. 15, 2017. [Online]. Available: https://doi.org/10.1016/j.energy.2017.09. 077

[57] X. Chen, "The Declining Value of Subscription-based Abstracting and Indexing Services in the New Knowledge Dissemination Era," Serials Review, vol. 36, no. 2, 2010. [Online]. Available: https://doi.org/10.1080/00987913.2010.10765288

[58] V. de A. Guimarães, G. M. Ribeiro, and M. de Azevedo-Ferreira, "Mapping of the Brazilian scientific publication on facility location," Pesquisa Operacional, vol. 38, no. 2, May. 16, 2018. [Online]. Available: https://doi.org/10.1590/0101-7438.2018.038.02.0307

[59] F. You, L. Tao, D. J. Graziano, and S. W. Snyder, “Optimal design of sustainable cellulosic biofuel supply chains: Multiobjective optimization coupled with life cycle assessment and input-output analysis," AlChE Journal, vol. 58, no. 4, Abr. 2012. [Online]. Available: https://doi.org/10.1002/aic.12637

[60] D. Yue, F. You, and S. W. Snyder, "Biomass-to-bioenergy and biofuel supply chain optimization: Overview, key issues and challenges," Computers \& Chemical Engineering, vol. 66, Jul. 4, 2014. [Online]. Available: https://doi.org/10.1016/j.compchemeng.2013.11.016

[61] S. Gold and S. Seuring, "Supply chain and logistics issues of bio-energy production," Journal of Cleaner Production, vol. 19, no. 1, Ene. 2011. [Online]. Available: https://doi.org/10.1016/j.jclepro. 2010.08.009

[62] D. Choudhary and R. Shankar, "An STEEP-fuzzy AHP-TOPSIS framework for evaluation and selection of thermal power plant location: A case study from India," Energy, vol. 42, no. 1, Jun. 2012. [Online]. Available: https://doi.org/10.1016/j.energy.2012.03.010

[63] A. Goodrich and et al., "A wafer-based monocrystalline silicon photovoltaics road map: Utilizing known technology improvement opportunities for further reductions in manufacturing costs," Solar Energy Materials and Solar Cells, vol. 114, Jul. 2013. [Online]. Available: https://doi.org/10.1016/j.solmat.2013.01.030

[64] S. Ahmad and R. M. Tahar, "Selection of renewable energy sources for sustainable development of electricity generation system using analytic hierarchy process: A case of Malaysia," Renewable Energy, vol. 63, Mar. 2014. [Online]. Available: https: //doi.org/10.1016/j.renene.2013.10.001

[65] K. McCormick and T. Kåberger, "Key barriers for bioenergy in Europe: Economic conditions, know-how and institutional capacity, and supply chain co-ordination," Biomass and Bioenergy, vol. 31, no. 7, Jul. 2001. [Online]. Available: https://doi.org/10.1016/j. biombioe. 2007.01 .008

[66] J. A. Scott, W. Ho, and P. K. Dey, "A review of multi-criteria decision-making methods for bioenergy systems," Energy, vol. 42, no. 1, Jun. 2012. [Online]. Available: https://doi.org/10.1016/j. energy.2012.03.074

[67] J. Zhang, A. Osmani, I. Awudu, and V. Gonela, "An integrated optimization model for switchgrass-based bioethanol supply chain," Applied Energy, vol. 102, Feb. 2013. [Online]. Available: https: //doi.org/10.1016/j.apenergy.2012.06.054

[68] F. Cucchiella and I. D'Adamo, "Issue on supply chain of renewable energy," Energy Conversion and Management, vol. 76, Dic. 2013. [Online]. Available: https://doi.org/10.1016/j.enconman.2013.07.081

[69] G. Corsano, A. R. Vecchietti, and J. M. Montagna, “Optimal design for sustainable bioethanol supply chain considering detailed plant performance model," Computers \& Chemical Engineering, vol. 35, no. 8, Ago. 10, 2011. [Online]. Available: https://doi.org/10.1016/j. compchemeng.2011.01.008

[70] F. Cucchiella, I. D'Adamo, and S. C. L. Koh, “Environmental and economic analysis of building integrated photovoltaic systems in Italian regions," Journal of Cleaner Production, vol. 98, Jul. 1, 2015. [Online]. Available: https://doi.org/10.1016/j.jclepro.2013.10.043

[71] J. R. Stokes and A. Horvath, "Sustainability of Natural Hazard Risk Mitigation: Life Cycle Analysis of Environmental Indicators for Bridge Infrastructure," Journal of Infrastructure Systems, vol. 19, no. 4, Dic. 2013. [Online]. Available: https://doi.org/10.1061/(ASCE) IS.1943-555X.0000138

[72] D. Chiaroni and et al., "Evaluating solar energy profitability: A focus on the role of self-consumption," Energy Conversion and Management, vol. 88, Dic. 2014. [Online]. Available: https: //doi.org/10.1016/j.enconman.2014.08.044

[73] S. A. R. Khan and et al., "Green supply chain management, economic growth and environment: A GMM based evidence," Journal of Cleaner Production, vol. 185, Jun. 218. [Online]. Available: https://doi.org/10.1016/j.jclepro.2018.02.226

[74] J. Andrews and B. Shabani, "Re-envisioning the role of hydrogen in a sustainable energy economy," International Journal of Hydrogen Energy, vol. 37, no. 2, Ene. 2012. [Online]. Available: https: //doi.org/10.1016/j.ijhydene.2011.09.137

[75] F. Cherubini and G. Jungmeier, "LCA of a biorefinery concept producing bioethanol, bioenergy, and chemicals from switchgrass," The International Journal of Life Cycle Assessment volume, vol. 15, no. 1, Ene. 2012. [Online]. Available: https://doi.org/10.1007/ s11367-009-0124-2

[76] X. Wu, X. Hu, S. Moura, X. Yin, and V. Pickert, "Stochastic control of smart home energy management with plug-in electric vehicle battery energy storage and photovoltaic array," Journal of Power Sources, vol. 333, Nov. 30, 2016. [Online]. Available: https://doi.org/10.1016/j.jpowsour.2016.09.157

[77] A. D. Rosa and J. E. Christensen, "Low-energy district heating in energy-efficient building areas," Energy, vol. 36, no. 12, Dic. 2011. [Online]. Available: https://doi.org/10.1016/j.energy.2011.10.001

[78] H. Lund, B. V. Mathiesen, P. Christensen, and J. H. Schmidt, "Energy system analysis of marginal electricity supply in consequential LCA," The International Journal of Life Cycle Assessment, vol. 15, no. 3, Feb. 13, 2010. [Online]. Available: https://doi.org/10.1007/ s11367-010-0164-7

[79] J. Dewulf, H. V. Langenhove, and B. V. D. Velde, "Exergy-Based Efficiency and Renewability Assessment of Biofuel Production," Environmental Science \& Technology, vol. 39, no. 10, Abr. 16, 2005. [Online]. Available: https://doi.org/10.1021/es048721b

[80] M. Varsei, C. Soosay, B. Fahimnia, and J. Sarkis, "Framing sustainability performance of supply chains with multidimensional indicators," Supply Chain Management, vol. 19, no. 3, May. 6, 2014. [Online]. Available: https://doi.org/10.1108/SCM-12-2013-0436 